\title{
下部構造に支持された免震大スパンアーチ模型の振動台実験 \\ SHAKING TABLE TESTS ON A SEISMICALLY-ISOLATED LARGE-SPAN ARCH SUPPORTED BY BASE STRUCTURES
}

\author{
松井徹哉*1，水野 啓示朗*2，杉山 映*3，江 坂 佳 賢*4，日比野 智也*5 \\ Tetsuya MATSUI, Keijiro MIZUNO, Ei SUGIYAMA, \\ Yoshisato ESAKA and Tomoya HIBINO
}

\begin{abstract}
Until recently few research efforts have been directed toward the application of seismic isolation systems in large-span spatial structures. This is due to the light weight and relatively long natural period of this type of structure which makes it difficult to apply the commonly used isolation system composed of laminated rubber isolators and dampers. In this paper, the use of a seismic isolation system with sliding mechanism is proposed for large-span spatial structures. In order to confirm its effectiveness in reducing the seismic response, shaking table tests are performed using a small-scale arch model supported by the base structures. It is confirmed that the proposed seismic isolation system is effective in reducing substantially the response due to horizontal ground motions. It is also demonstrated that the response of the arch is significantly influenced by the dynamic properties of the base structures, but can be well predicted by the dynamic response analysis considering the arch-base structure interaction.
\end{abstract}

Keywords: Spacial structure, Arch, Seismic isolation, Base structure, Sliding bearing, Shaking table test 空間構造 アーチ 免震 下部構造 転がり支承 振動台実験

\section{1. 序}

ドームをはじめとする空間構造は，公共性の高い施設として常 時不特定多数の人々に利用され，また災害時には避難・復旧の拠 点としての役割も期待され，一般の建築物に比べてより高い安全 性が要求される。1995 年兵庫県南部地震では空間構造の被害が支 承部や下部構造に集中して見られたことから ${ }^{1)}$ ，その後空間構造 の上部構造と下部構造の連成振動に着目した研究が行われるよう

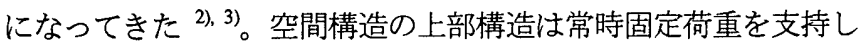
なければならないため, 損傷後の部材交換が容易でないことや, 破壊形式が座屈など脆性的で塑性化後のエネルギー吸収が期待で きないことから，最大級の地震に対しても上部構造を弾性範囲に とどめる設計が望ましい。

空間構造の上部構造を弾性範囲にとどめより高い耐震性能を 保証するためには，下部構造との間に免震機構を導入することが 有効であると考えられる。一般の中高層建築物における免震化の 有効性についてはすでに確認されているところであり, 設計指針 4) も整備され，実施例も近年急増してきている。一方，空間構造
の免震化については, 加藤ら ${ }^{5-7)}$, 川口ら ${ }^{8)}$ の研究によってその 有効性が明らかにされ，実施例も出現しつつあるが ${ }^{9)}$ ，研究，実 施例ともに中高層建築物に比べて少ないのが現状である。特に, 免震の効果を実験，実測等により検証した研究は，扁平シェルの 上下免震を扱った新宮ら ${ }^{10)}$ の研究以外には見当たらない。

空間構造物は一般に軽量で固有周期が比較的長いため，従来の 積層ゴムと履歴ダンパーからなる免震装置では免震周期を十分伸 長することが困難になる場合が予想される。また積層ゴムはその 特性が上部構造の重量, ひずみレベル, 温度など, 種々の要因に 依存するため, 適用に際して制約を受けるという難点がある。川 ロら ${ }^{8)}$ は, 上部構造の重量や免震装置の力学特性に左右されるこ となく長周期免震を実現するために, 振り子原理を利用したパド ル型免震を考案し，その効果を実証している。著者ら ${ }^{11}$ は住宅や 高層建築物の免震に採用されているすべり支承や転がり支承を空 間構造物に用いることを検討し，大スパンアーチやドームに適用 した場合の免震効果を模型実験及び解析により確認している。ま た別稿 ${ }^{12)}$ では，大スパン単層ラチスドームを対象に風の動的作用
*1 名城大学理工学部建築学科 教授. 工博

*2 名古屋大学大学院工学研究科 大学院研究生 ·博士 (工学)

*3 伊藤建築設計事務所

*4 日建設計

*5 東京工.業大学総合理工学研究科人間環境システム尃攻 大学院生
Prof., Dept. of Architecture, Faculty of Science and Technology, Meijo Univ., Dr. Eng.

Graduate Student, Graduate School of Engineering, Nagoya Univ., Dr. Eng.

Ito Architects and Engineers Inc.

Nikken Sekkei Co., Ltd.

Graduate Student, Dept. of Built Environment, Graduate School of Science and

Engineering, Tokyo Institute of Technology 
を考慮した応答解析を行い，長周期化に伴う免震層の応答変位に ついての検討を行うとともに，風応答を考慮した免震層パラメー タの設定法を提案している。

本稿では，下部構造との間に転がり支承と積層ゴム支承の併用 による免震層の導入を想定した大スパンアーチ模型の振動台実験 を行い，免震化による応答低減効果や下部構造の剛性が全体系の 忘答性状に及ぼす影響を実験的に確認する。さらに, 実験のシミュ レーションを行い，実験結果と比較することによりシミュレー ション手法 ${ }^{13)}$ の妥当性を検証するとともに, ア一チ一免震層一下 部構造連成系の振動性状とエネルギー授受の関係について総括的 考察を行う。

\section{2。実験模型}

実験に用いる縮小模型は一般的には，実構造物と相似則が成り 立つものであることが理想的であるが，今回の実験においてその ような相似模型を製作すると,アーチ部分の剛性が高くなり,アー チの振動を定量的に捉えることは困難であると予想された。そこ で，免震アーチ模型のアーチ部分の固有周期をこの種の実在構造 物の固有周期と同程度にすることを設計方針とした。

実験に用いた模型は図 1-1，1-2 に示すようなアーチ単体モデル (O モデル) とその両端を下部構造で支えた連成系モデル $(\mathrm{A} \cdot \mathrm{B}$ 。 $\mathrm{C}$ モデル) であり，その諸元を表 1-1，1-2 及び表 2 に，各部の質

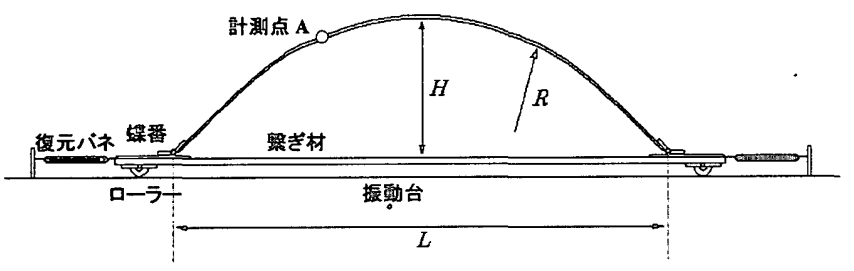

図 1-1 実験模型（Oモデル）

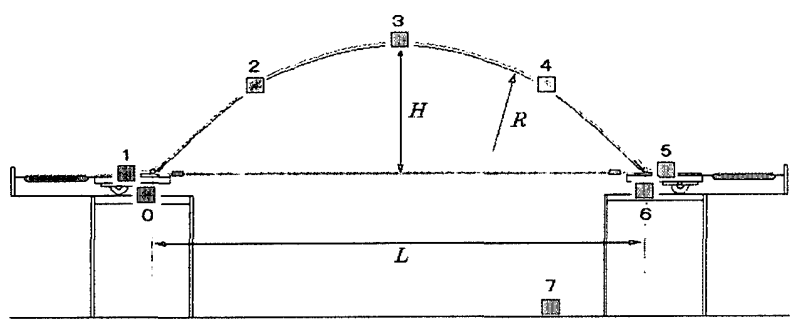

図 1-2 実験模型 $(\mathrm{A} ・ \mathrm{~B} ・ \mathrm{C}$ モデル)

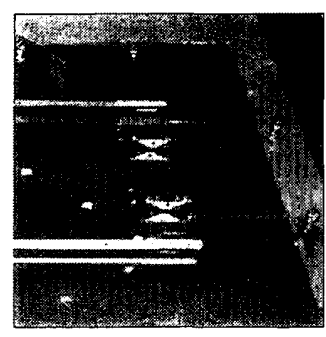

$\mathrm{O}$ モデル

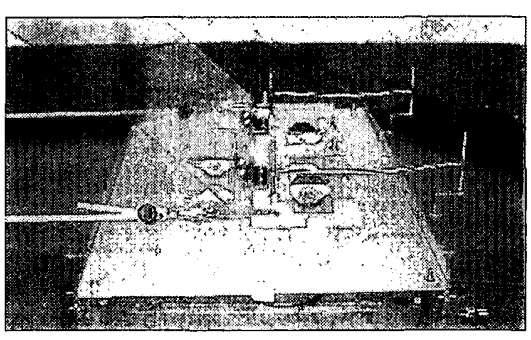

$\mathrm{A} \cdot \mathrm{B} \cdot \mathrm{C}$ モデル
図 2 免震アーチ支承部
表1-1 模型の諸元（上部構造）表1-2 模型の諸元 (下部構造)

\begin{tabular}{|c|c|}
\hline スパン $\mathrm{L}(\mathrm{mm})$ & 780 \\
\hline ライズ $\mathrm{H}(\mathrm{mm})$ & 212.5 \\
\hline 曲率半径 $\mathrm{R}(\mathrm{mm})$ & 480.6 \\
\hline 幅 $(\mathrm{mm})$ & 300 \\
\hline 厚さ $(\mathrm{mm})$ & 1 \\
\hline
\end{tabular}

\begin{tabular}{|c|c|}
\hline スラブ幅 $(\mathrm{mm})$ & 250 \\
\hline スラブ奥行 $(\mathrm{mm})$ & 400 \\
\hline 柱高 $(\mathrm{mm})$ & 250 \\
\hline 柱厚 $(\mathrm{mm})$ & 2,5 \\
\hline 柱幅 $(\mathrm{mm})$ & 15 \\
\hline
\end{tabular}

表 2 計測点の位置

\begin{tabular}{|c|c|c|c|}
\hline モデル & 計測点 & $\mathrm{x}(\mathrm{cm})$ & $\mathrm{y}(\mathrm{cm})$ \\
\hline $\mathrm{O}$ & $\mathrm{A}$ & 23.26 & 18.11 \\
\hline \multirow{3}{*}{$\mathrm{A} \cdot \mathrm{B} \cdot \mathrm{C}$} & 2 & 16.93 & 14.61 \\
\cline { 2 - 4 } & 3 & 39.13 & 21.25 \\
\cline { 2 - 4 } & 4 & 61.07 & 14.78 \\
\hline
\end{tabular}

( $\mathrm{x}, \mathrm{y}$ : アーチ左支持端からの水平・鉛直距離)

表3-1 模型各部の質量 (Oモデル)

\begin{tabular}{|c|c|c|}
\hline 模型質量 & 非免震 & 免震 \\
\hline 上部構造 $:$ ア一チ部 $(\mathrm{g})$ & \multicolumn{2}{|c|}{410} \\
\hline 上部構造 : 支承部 $(\mathrm{g})$ & 0 & 328 \\
\hline
\end{tabular}

表3-2 模型各部の質量（A・B・Cモデル）

\begin{tabular}{|c|c|c|}
\hline 模型質量 & 左端 & 右端 \\
\hline 上部構造 $:$ アーチ部 $(\mathrm{g})$ & \multicolumn{2}{|c|}{410} \\
\hline 上部構造 : 支承部 $(\mathrm{g})$ & 182 & 182 \\
\hline 下部構造 : スラブ部 $(\mathrm{g})$ & 735 & 729 \\
\hline 下部構造 $:$ 柱 $2 \mathrm{~mm}(\mathrm{~g} / 1$ 本 $)$ & \multicolumn{2}{|c|}{9.3} \\
\hline 下部構造 : 柱 $5 \mathrm{~mm}(\mathrm{~g} / 1$ 本 $)$ & \multicolumn{2}{|c|}{23.5} \\
\hline
\end{tabular}

表4 材料定数等

\begin{tabular}{|c|c|c|c|}
\hline 材料 & 定数 & Oモデル & $\mathrm{A} \cdot \mathrm{B} \cdot \mathrm{C} モ テ ゙ ル$ \\
\hline 硬質塩化ビニール & 弹性係数 $\left(\mathrm{kN} / \mathrm{mm}^{2}\right)$ & $2.55 \sim 3.24$ & $2.55 \sim 3.24$ \\
\hline アクリル & 弾性係数 $\left(\mathrm{kN} / \mathrm{mm}^{2}\right)$ & $\sim$ & 2.94 \\
\hline 䋈ぎ材:ヨ゙ム & 伸ひ㴊性(N/cm/1本) & $\sim$ & 0.249 \\
\hline 免震層:バネ & バネ定数(N/cm/1本) & 0.0168 & 0.0172 \\
\hline 兔震層:ローラー & 静止摩擦保数 & 0.03 & 0.034 \\
\hline
\end{tabular}

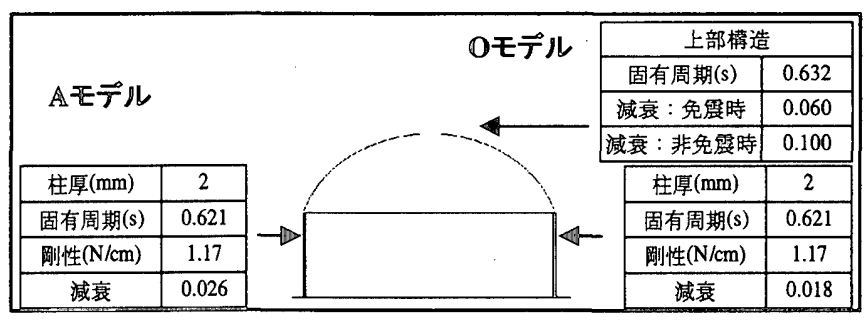

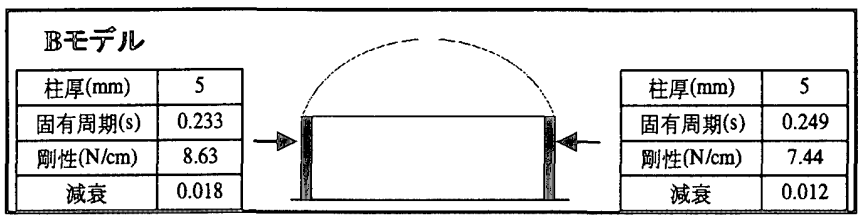

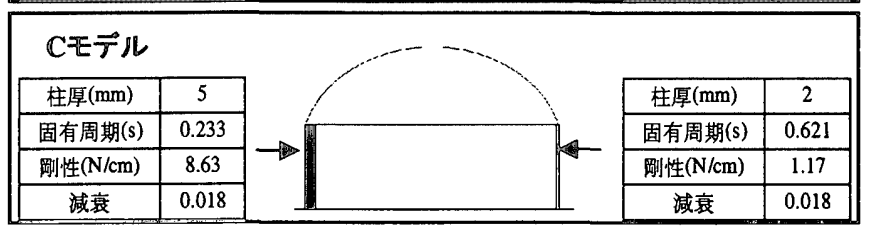

図 3 下部構造モデル 
量を表 3-1，3-2 に，また計測により求めた材料定数等を表 4 に示 す。アーチ部分は全モデルに共通であり, $\mathrm{A} \cdot \mathrm{B} \cdot \mathrm{C}$ モデルはこれ を両端にてそれぞれ独立に下部構造で支える形式になっている。 アーチ部分の模型材料には硬質塩化ビニール平板（厚さ $1 \mathrm{~mm}$ ) を選定し,これをアーチ状に曲げて両端を 2 本の慗ぎ材で緊結し， 両端ピン支持条件を実現するため，支持部において蝶番を介して 下部構造または免震層に固定した。繋ぎ材はアーチ形状を保つと ともに上下地震動によって生じるアーチの水平推力を支える役割 を果たすもので，O モデルでは軽量で軸剛性の高いアルミニウム 製の繋ぎ材を用いているが, $\mathrm{A} ・ \mathrm{~B} ・ \mathrm{C}$ モデルでは，下部構造の剛 性の不均一性が上部構造に与える影響を把握するため, 左右柱の 周期特性の異なる振動を繋ぎ材が拘束することのないように, 剛 性の低いゴム製の繋ぎ材に変えている。

免震層には転がり支承と積層ゴム支承を併用した免震デバイ スを想定し，実験モデルでは，図 2 に示すように，これらを 4 個 のローラーと 4 本のバネ (外径: $5 \mathrm{~mm}$, 線径 : $0.3 \mathrm{~mm}$ ) で置換し, 免震周期 (バネのみの固有周期, 上部構造を剛体と仮定）が約 3 秒となるようにバネ定数を調整している。なお，バネには最大変 位時にも弛みが生じずかつ線形範囲で挙動することを確認した上 で, 約 $6 \mathrm{~cm}$ の初期変位を与えている。

下部構造は剛なスラブを 4 本のアクリル製の柱で支える 1 層せ ん断型骨組であり，柱材の厚さを変化させることにより水平剛性 を調整できるようにしてある。今回実験に用いた下部構造モデル は図 3 に示す 3 モデルであり, A モデルは下部構造と上部構造の 固有周期が接近したモデル，B モデルは下部構造の固有周期が上 部構造の固有周期に比べて短いモデル（実際にはこのケースが多 い), $\mathrm{C}$ モデルは左右の柱の固有周期が異なるモデルである。ス ウィープ加振実験及び RD 法 ${ }^{14)}$ により算出した各部の剛性, 固 有周期及び減衰定数を図 3 に示す。なお，ここに示す下部構造の 固有周期は上部構造を剛体と仮定したときの固有周期であり, アーチ部及び支承部の全質量の $1 / 2$ に見合う付加質量を各スラブ に上載してスウィープ加振実験を行って得た值である。スウィー

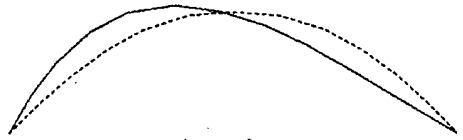

1次モード $/ 0.632 s$

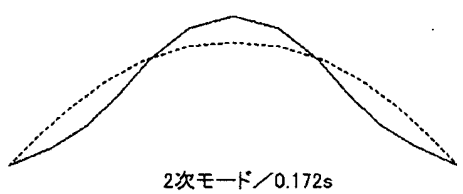

図4 固有周期と固有振動モード (Oモデル・非免震時) プ加振実験の結果, 非免 震時のアーチ単体モデル (Oモデル) の1次及び 2 次固有周期は 0.632 秒 と 0.172 秒であり, それ ぞれ図 4 に示すような水 平逆対称と上下対称の モード形を示した。免震 周期はOモデルで 3.0 秒, $\mathrm{A} \cdot \mathrm{B} \cdot \mathrm{C}$ モデルで 2.9 秒 であり, 十分な免震効果 が期待できる。

\section{3. 実験・計測方法}

実験には，名古屋大学工学部 9 号館設置の水平・上下二軸振動 台を用い，非免震及び免震ア一チ模型に対して地震波加振を行っ た。地震波には El Centro (1940) の NS, UD 成分をそれぞれ水平, 上下地震動として用い，最大水平加速度が O モデルでは $300 \mathrm{gal}$,
$\mathrm{A} \cdot \mathrm{B} \cdot \mathrm{C}$ モデルでは下部構造による増幅を考慮して $150 \mathrm{gal}$ (アー チ基部で $300 \mathrm{gal}$ 相当) となるように同倍率化して同時入力させた。 各アーチ模型上の 5 点（O モデルでは 7 点）の水平・上下方向の 絶対変位を非接触画像処理変位計測装置にて，また振動台上及び 下部構造頂部（左・右端）の3 点の水平・上下加速度を歪ゲージ 型加速度計にて計測した。

\section{4. 実験結果}

$\mathrm{O}$ モデルについて, 非免震時及び免震時の計測点 $\mathrm{A}$ の変位応答 波形を図 5 に示す。ここで，変位応答は非免震ア一チの場合は振 動台との, 免震アーチの場合は免震層との相対変位である。非免 震アーチでは，水平方向のみならず上下方向にも大きく忘答して おり,これは刺激係数の大きいアーチの 1 次水平逆対称モード(図 4 上）が励起されたためと考えられる。一方，免震ア一チではこ れら水平・上下方向の大きな応答が十分に低减されているのが確 認できる。一般の中高層建築物では免震層の導入は上下応答の低 減には寄与しないが, アーチのような空間構造物では水平逆対称 モードが大きな上下応答を伴うという特有の振動性状により, 地 震動の水平入力成分の低減による上下応答の低減効果が十分期 待できる。図 6 は復元バネの有無による免震層の変位応答を比較 したものである。図よりバネを併用することが免震層の降伏後の 復元性を付与し，残留変位の抑制に効果的であることが分かる。

次に A・B・C モデルについて，下部構造頂部（計測点 $0,6 ）$

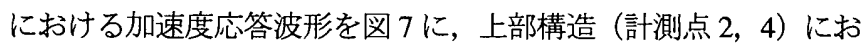
ける変位応答波形を図 8 に示す。ただし，変位波形は計測点 2 に おいては上部構造左端部（計測点 1) に対する相対変位, 計測点 4 においては上部構造右端部 (計測点 5) に対する相対変位である。
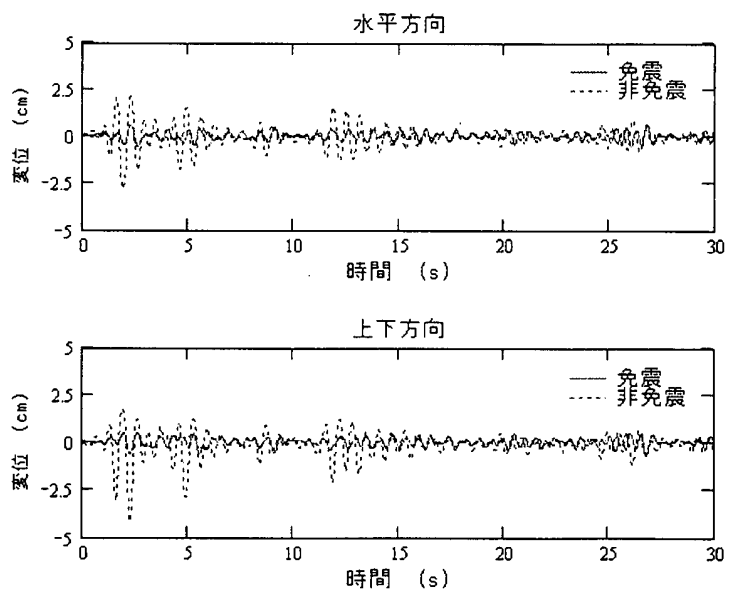

図 5 上部構造変位応答計測波形（O モデル：計測点 $\mathrm{A}$ )

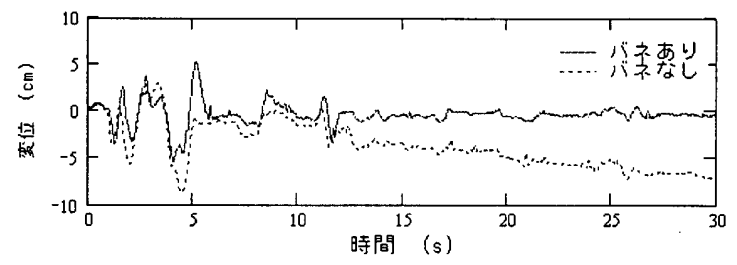

図 6 復元バネの有無による免震層変位応答計測波形の比 較 (O モデル) 


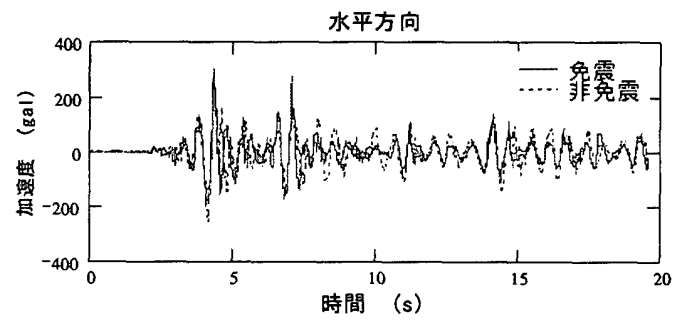

$\mathrm{A}$ モデル $(2 \mathrm{~mm}-2 \mathrm{~mm}):$ 計測点0

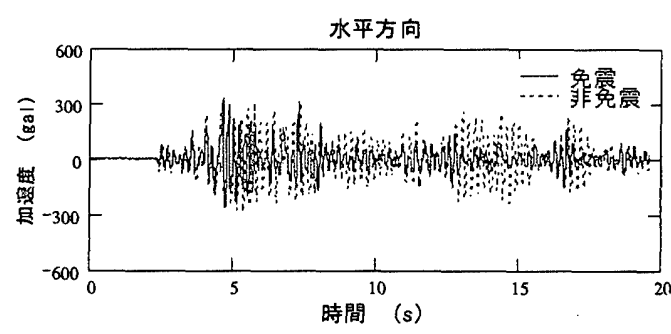

Bモデル $(5 \mathrm{~mm}-5 \mathrm{~mm})$ : 計測点0

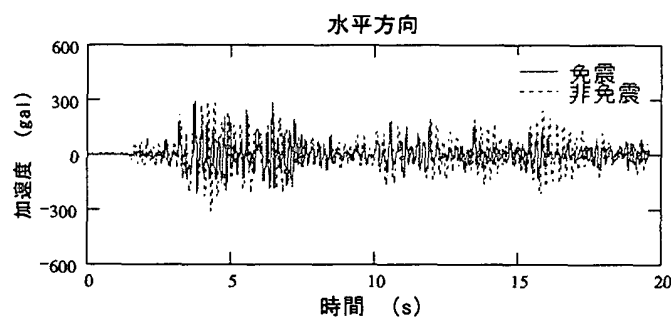

Cモデル $(5 \mathrm{~mm}-2 \mathrm{~mm}):$ 計測点 0

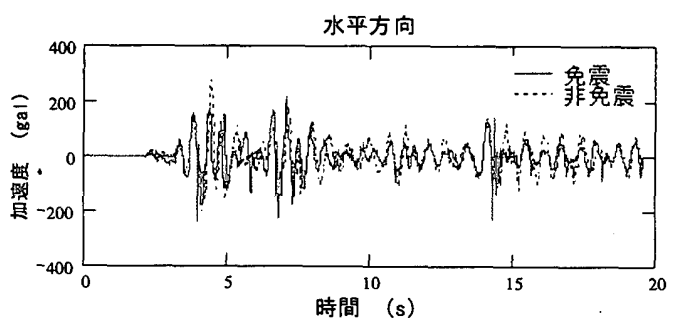

Aモデル $(2 \mathrm{~mm}-2 \mathrm{~mm})$ : 計測点6

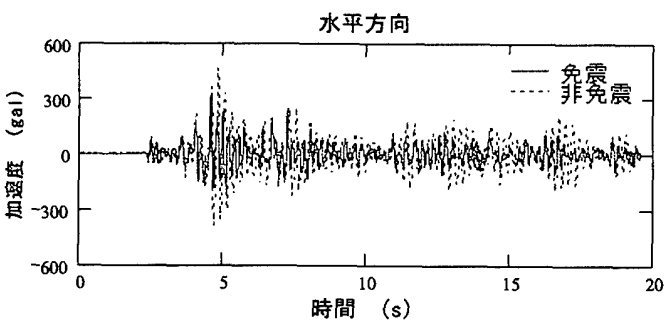

Bモデル $(5 \mathrm{~mm}-5 \mathrm{~mm})$ : 計測点6

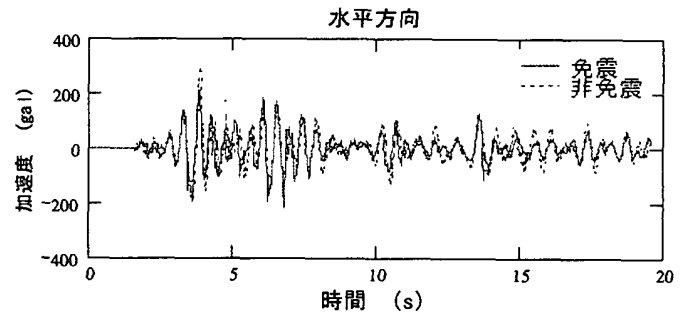

Cモデル $(5 \mathrm{~mm}-2 \mathrm{~mm}):$ 計測点6

図 7 下部構造加速度応答計測波形 $(A \cdot B \cdot C$ モデル $)$

非免震時には, 下部構造の加速度応答は下部構造の剛性が高く なるほど（A， C，B の順に）増大する傾向が見られる。一方，上 部構造の変位态答は下部構造の剛性が低くなるほど（B, C, A の 順に）増大する傾向が見られる。特に上部構造と下部構造の固有 周期を意図的に近づけた A モデルでは, 上部構造が TMD の役割 を果たして下部構造の振動エネルギーを吸収するいわゆる TMD 効果により，下部構造の応答が減少する一方，上部構造の応答が 著しく増大している。また左右柱の剛性が異なる C モデルでは, 剛柱側に近い計測点 2 において柔柱側に近い計測点 4 よりも大き な応答が水平及び上下方向に発生している。これは, 図 7 から明 らかなように, 剛柱側（計測点 0) により大きな加速度が入力さ れるからだと考えられる。

免震化による効果は下部構造の加速度応答に対しては小さく, 剛性の小さな A モデルや C モデルの柔柱側（計測点 6）では, 免 震時の方が逆に非免震時よりも応答が大きくなっている。これは 免震化により上下間の連成が弱まり，下部構造が主に振動する モード (図 10-1，10-2) が励起されたためだと考えられる。一方, 上部構造の変位応答に対しては, 水平, 上下成分ともに効果的な 低減がなされ，特にC モデルでは下部構造の剛性不均一性に伴う 過大応答の発生も抑制されている。

以上により，本実験で想定した転がり支承と積層ゴム支承の併 用による免震デバイスは空間構造の免震化に有効であることが確
認できた。

\section{5. シミュレーションによる壆察}

\section{1 解晰モテ゚ル}

解析モデルは実験に用いた非免震及び免震アーチ模型とし， アーチ部分を 12 等分して各点間を直線材置換した骨組として, 下 部構造を 1 層せん断型骨組としてモデル化した。実験時, アーチ 形状を保つためにアーチの両端を結ぶ慗ぎ材に張力を加えている ため, 初期軸力導入に伴うアーチ部分の剛性への影響をオイラー 座屈荷重に等しい軸力が作用していると仮定し幾何剛性として考 慮した。アーチ材料の硬質塩化ビニールなどのプラスチックの弾 性係数は温度の影響を受けやすいことが知られており, 計測を 行ったところデータにばらつきが見られたが (表 4参照)，解析で はその中間値 $2.9 \mathrm{kN} / \mathrm{mm}^{2}$ を採用した。

免震層は転がり支承と弾性バネの並列システムからなる 1 質点 系としてモデル化し，その復元力特性を次式で与えた（図 9)。

$$
Q=\mu M g \operatorname{sgn}(\dot{\delta})+K \delta, \quad \operatorname{sgn}(\dot{\delta})=\left\{\begin{array}{cc}
1, & \dot{\delta}>0 \\
0, & \dot{\delta}=0 \\
-1, & \dot{\delta}<0
\end{array}\right.
$$

ここに, $Q$ : せん断力, $\mu$ : 転がり摩擦係数, $M$ : 質量, $g$ : 重力加速度, $K$ : バネ定数, $\dot{\delta}:$ 層間速度, $\delta$ : 層間変位である。 

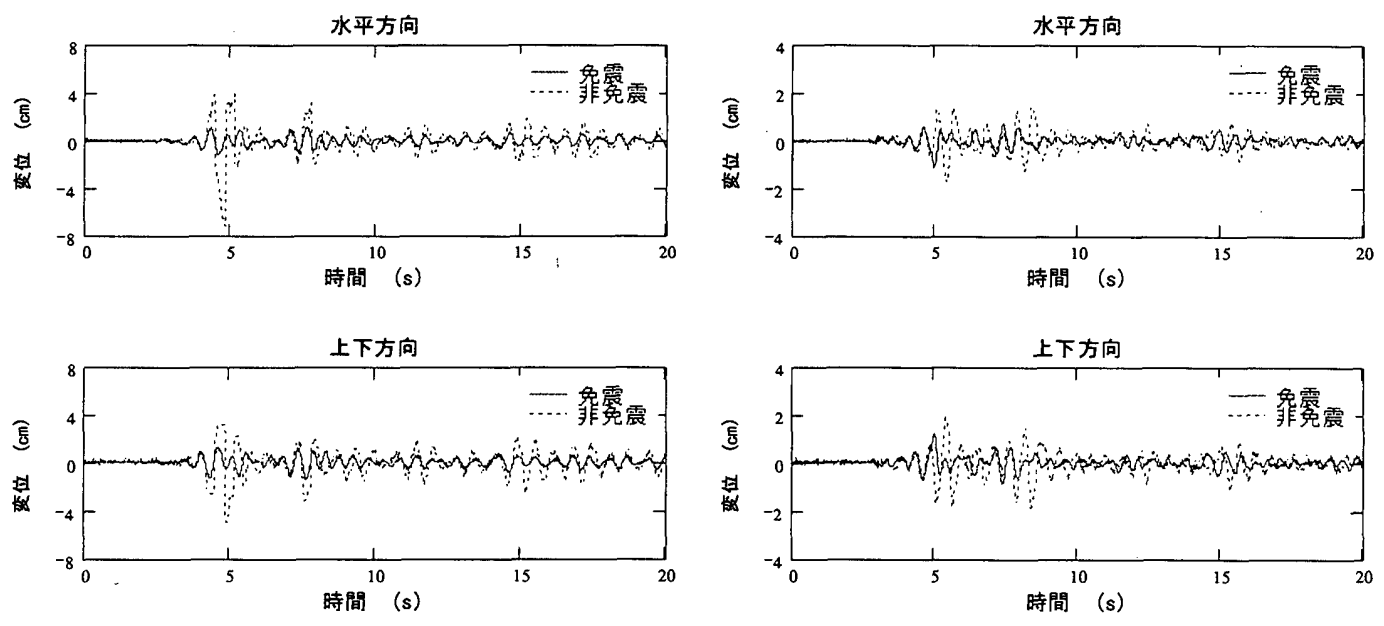

Aモデル (2mm-2mm) : 計測点2

Bモデル $(5 \mathrm{~mm}-5 \mathrm{~mm}) ：$ 計測点 2
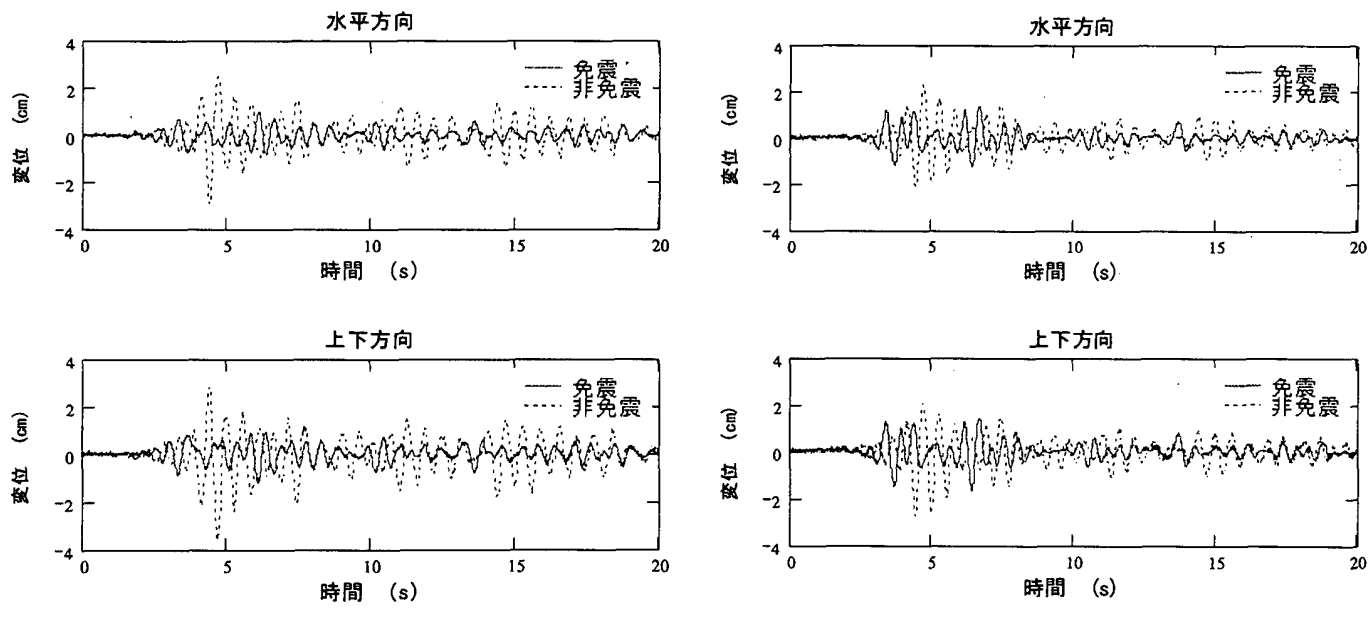

Cモデル $(5 \mathrm{~mm}-2 \mathrm{~mm}):$ 計測点2

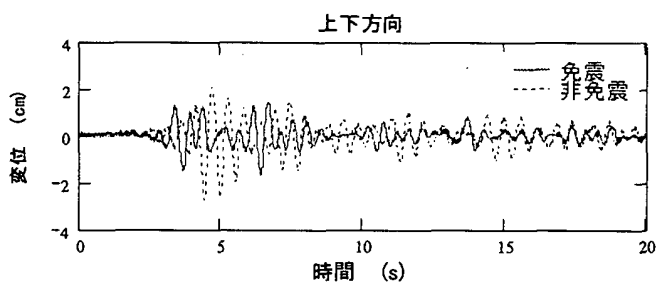

Cモデル $(5 \mathrm{~mm}-2 \mathrm{~mm}):$ 計測点 4

図 8 上部構造変位応答計測波形 $(\mathrm{A} \cdot \mathrm{B} \cdot \mathrm{C}$ モデル $)$

質量 $M$ としてはアーチ部と支承部の全質量が左右の免震層に 均等に作用すると仮定してその $1 / 2$ を採り, 転がり摩擦倸数 $\mu$ 及 びバネ定数 $K$ として表 4 に示す值を採用した。また減衰として上 部構造に対してはレーリ一型減衰を，下部構造に対しては剛性比 例型減衰を仮定し, 図 3 に示された各部の減衰定数值を用いて全 体系の減衰を評価した。免震層の減衰は無視した。したがって全 体系としての減衰は非比例型減衰となっている。

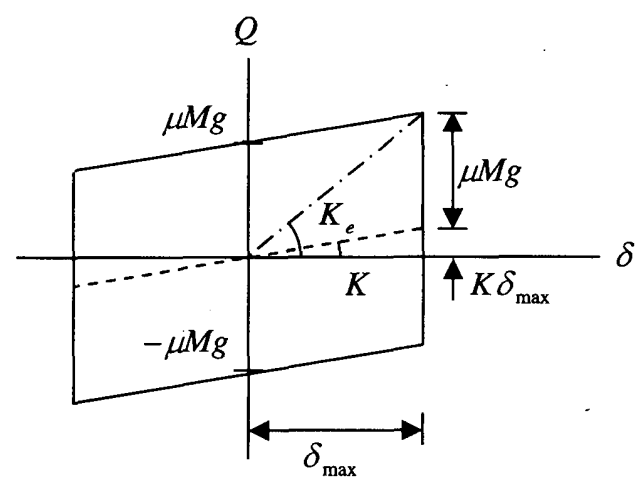

図 9 免震層の復元力特性

\section{2 固有振動解析}

初期軸力導入に伴う剛性低下を考慮して算定した非免震時の アーチ単体モデル (O モデル) の 1 次及び 2 次固有周期はそれぞ れ 0.635 秒と 0.179 秒であり，実験值 0.632 秒と 0.172 秒（図 4) に非常によく一致している。

固有值解析によって得られた $\mathrm{A} ・ \mathrm{~B} ・ \mathrm{C}$ モデルの非免震時・免震 時の固有周期及び刺激係数を表 5-1, 5-2 に, 固有振動モードを図 10-1，10-2 に示す。ここで，免震層の等価剛性は，図 11 を参考 に, 最大変位 $2 \mathrm{~cm}$ に対応する復元力特性上の割線剛性で評価して いる。表 5-1, 5-2 中の刺激係数 $\beta_{x}, \beta_{z}$ と入力地震動の加速度 応答スペクトル $S_{A x}, S_{A z}$ (10\%減衰時) との積 $\beta_{x} S_{A x}, \beta_{z} S_{A z}$ (指 標 $x, z$ は水平・上下成分に対応） は最大加速度応答への各モ一 ドの寄与度を示す指標となる。水平成分のみに着目すると, 非免 震時には, 下部構造と上部構造の固有周期が接近している A モデ ルでは TMD 効果により上部構造が主に振動する 1 次，2 次モード の奇与が支配的であるのに対し，下部構造の固有周期が上部構造 に比べて短い $\mathrm{B} ・ C$ モデルでは，下部構造の固有周期で振動する 2 次, 3 次モードが卓越している。特に下部構造の剛性が不均一な C モデルでは，左右柱の周期特性の異なる振動によって上部構造に 
表 5-1 固有振動特性（非免震時）

\begin{tabular}{|c|c|c|c|c|c|c|}
\hline \multirow{2}{*}{ モデル } & 次数 & 固有周期 & \multicolumn{2}{|c|}{ 刺激係数 } & \multirow{2}{*}{$\beta_{x} S_{A x}$} & \multirow{2}{*}{$\beta_{z} S_{A z}$} \\
\cline { 4 - 5 } & & $(\mathrm{s})$ & $\beta_{x}$ & $\beta_{z}$ & \\
\hline & 1 & 0.709 & 1.177 & -0.004 & 201 & -0.1 \\
& 2 & 0.533 & 0.964 & 0.01 & 250.1 & 0.4 \\
& 3 & 0.472 & -0.02 & 0.216 & -5.1 & 9.5 \\
& 4 & 0.176 & 0.001 & -0.082 & 0.1 & -9.7 \\
\hline \multirow{4}{*}{ B } & 1 & 0.639 & -0.485 & 0.007 & -101.5 & 0.3 \\
& 2 & 0.239 & -0.897 & 0.156 & -245.5 & 14.4 \\
& 3 & 0.223 & 1.153 & 0.12 & 280.2 & 11.1 \\
& 4 & 0.174 & -0.039 & -0.116 & -10.2 & -14.1 \\
\hline & 1 & 0.661 & -0.771 & 0.051 & -152.8 & 1.9 \\
C & 2 & 0.502 & -0.841 & 0.141 & -222.3 & 6.2 \\
& 3 & 0.224 & 1.009 & 0.141 & 245.8 & 13 \\
& 4 & 0.175 & -0.154 & -0.103 & -40.2 & -12.4 \\
\hline
\end{tabular}

表 5-2 固有振動特性（免震時）

\begin{tabular}{|c|c|c|c|c|c|c|}
\hline \multirow{2}{*}{ モデル } & 次数 & 固有周期 & \multicolumn{2}{|c|}{ 剌激係数 } & \multirow{2}{*}{$\beta_{x} S_{A x}$} & $\beta_{z} S_{A z}$ \\
\cline { 4 - 5 } $\mathrm{s})$ & $\beta_{x}$ & $\beta_{z}$ & \\
\hline & 1 & 1.34 & 1.017 & -0.001 & 52.3 & 0 \\
& 2 & 0.546 & 0.435 & 0.011 & 110 & 0.5 \\
& 3 & 0.49 & 0.05 & 0.082 & 13.1 & 3.5 \\
& 4 & 0.476 & 1.043 & -0.009 & 266.2 & -0.4 \\
\hline \multirow{4}{*}{ B } & 1 & 1.291 & 0.899 & -0.001 & 54.3 & 0 \\
& 2 & 0.539 & 0.126 & 0.011 & 32.4 & 0.5 \\
& 3 & 0.406 & -0.004 & 0.359 & -0.8 & 21.1 \\
& 4 & 0.202 & 0.877 & 0.004 & 203.4 & 0.4 \\
& 5 & 0.188 & 0.883 & -0.002 & 219 & -0.2 \\
\hline & 1 & 1.314 & 0.958 & -0.002 & 53.6 & 0 \\
& 2 & 0.543 & 0.297 & 0.001 & 75.7 & 0 \\
$\mathrm{C}$ & 3 & 0.482 & 0.732 & -0.066 & 189 & -2.9 \\
& 4 & 0.404 & 0.152 & 0.354 & 29.5 & 20.9 \\
& 5 & 0.188 & 0.882 & -0.002 & 218.9 & -0.2 \\
\hline
\end{tabular}

大きな応答が生じている。一方, 免震時には，上下間の連成が弱 まることにより，下部構造が主に振動する A モデルの 4 次， B モ デルの 4 次, 5 次, $C$ モデルの 3 次, 5 次のモードが支配的となっ ている。前節に示した実験結果の傾向はこれらのモード特性を反 映したものとなっている。

\section{3 時刻歴俯答シミュレーション}

振動台上で計測された加速度波形の水平・上下成分を入力地震 動として, ニューマークの $\beta$ 法による時刻歷応答シミュレーショ ンを行った。応答解析には, 全体系を上部構造と免震層を含む下 部構造とに分割するサブストラクチャー法 ${ }^{13)}$ を適用した。この方 法法，上部構造の弾性を前提とし，その応答を下部構造の変位に よる淮静的変位と下部構造固定時の固有振動モ一ドの重ね合わせ で表現することによって運動方程式の自由度を縮約して解くもの で，フルモデルによる解析に比べて格段に効率的である上に，上 部構造と下部構造とで減衰機構が異なる場合でも減衰マトリック スの対角性を保持したまま解析を進めることができる。本シミュ レーションでは, 上部構造のモード分解には 5 次までの固有振動 モードを採用した。

$\mathrm{C}$ モデルの免震層における水平変位応答, 下部構造頂部（計測 点 $0,6 ）$ における水平加速度応答及び上部構造（計測点 2）にお ける水平。上下変位応答（計測点 1 との相対変位）の解析結果を 図 11 , 図 12 及び図 13 に, それぞれ実験結果と比較して示す。大
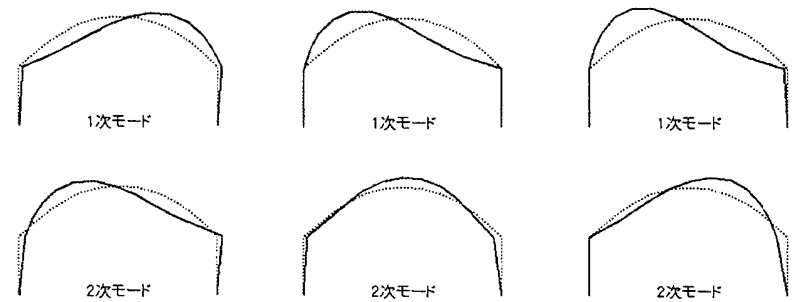

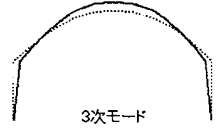

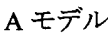

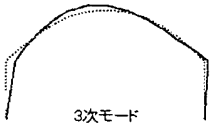

$\mathrm{B}$ モデル

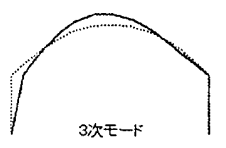

$\mathrm{C}$ モデル
図 10-1 固有振動モード（非免震時）
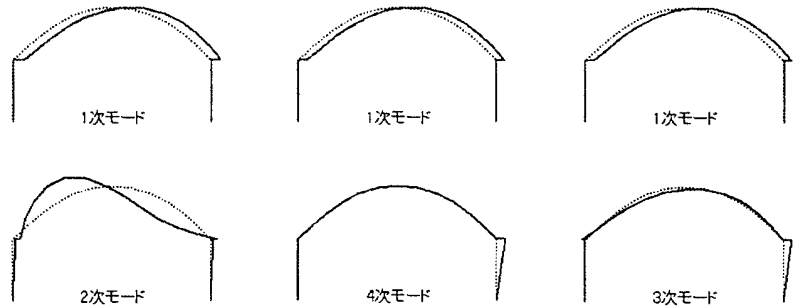

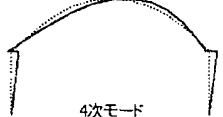

$\mathrm{A}$ モデル

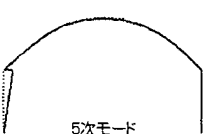

Bモデル

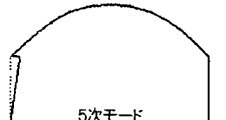

$\mathrm{C}$ モデル
図 10-2 固有振動モード (免震時)
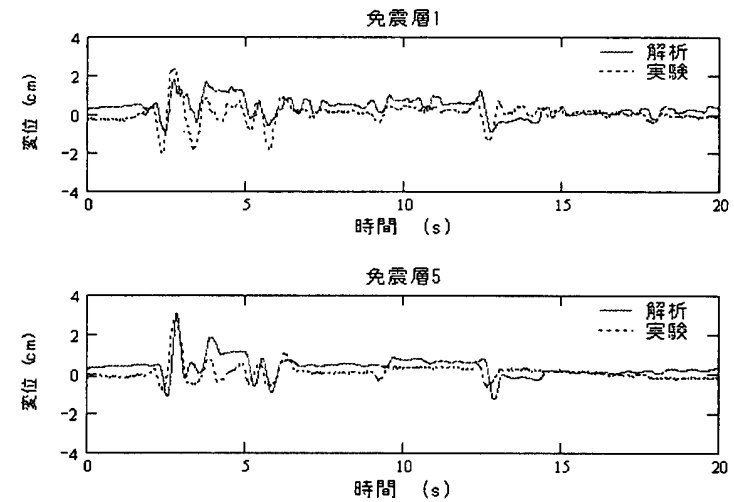

図 11 免震層変位応答波形 ( $\mathrm{C}$ モデル) 一実験とシミュレー ションの比較—

振幅時及び免震時に若干の相違が見受けられるものの両者の傾 向は非常によく一致している。この相違は，解析では幾何学的非 線形効果を考慮していないことと，動摩擦保数を静摩擦係数で代 用しているなど，免震層における摩擦，復元バネの挙動などのモ デル化に厳密性を欠く要因が残されていることの影響であると 考えられ，時刻歴応答シミュレーションにより実現象を十分正確 に再現し得ることが明らかになった。 

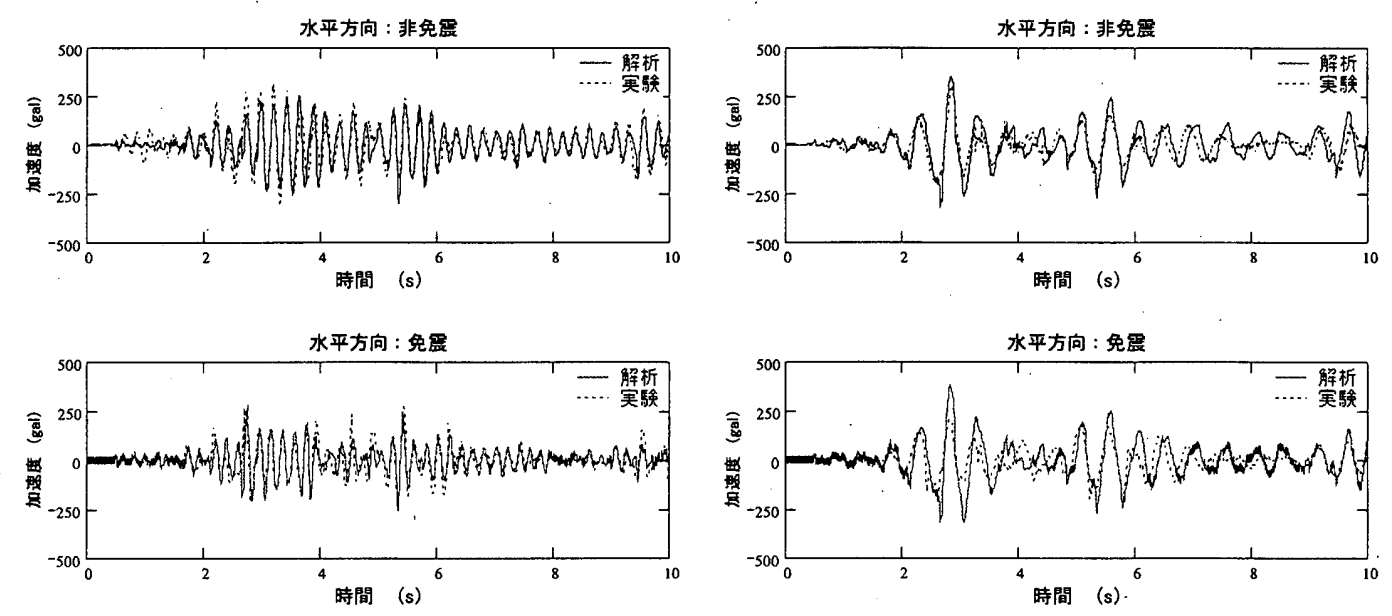

計測点 0

計測点 6

図 12 下部構造加速度応答波形（Cモデル）一実験とシミュレーションの比較—
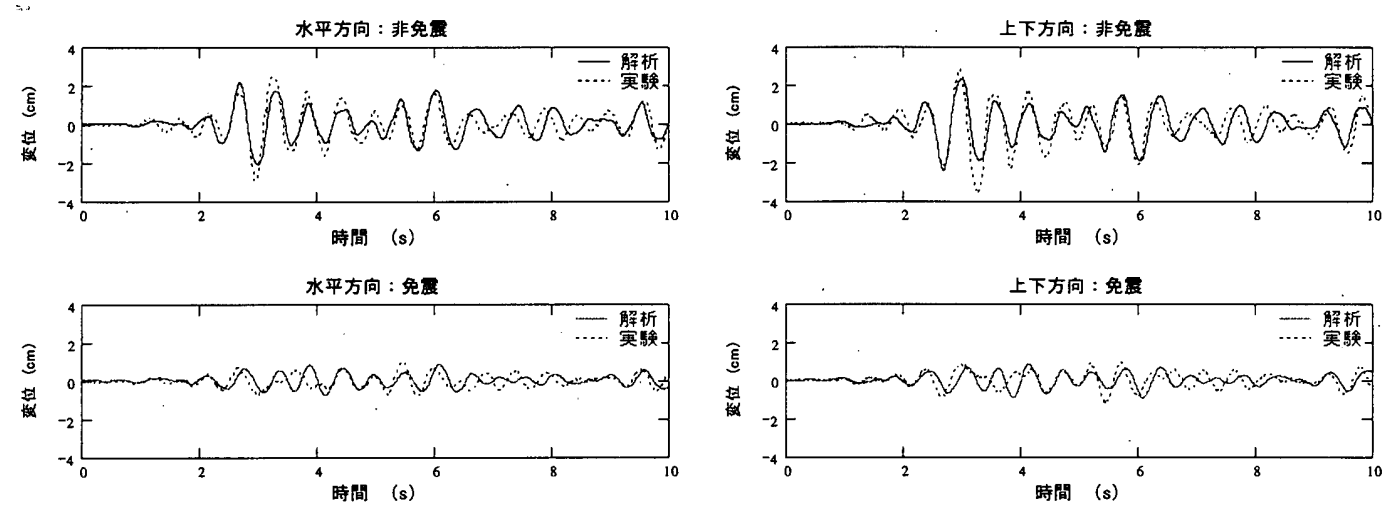

図 13 上部構造変位応答波形（Cモデル：計測点 2 ）一実験とシミュレーションの比較—

\section{4 エネルギ一釣合に基つくく包絡解析}

振動台上で計測された加速度波形の水平成分を入力したとき のエネルギー応答の時刻歴を C モデルについて図 14 に示す。図 中, $W_{e}$ は弾性振動エネルギー, $W_{h}^{a}$ は上部構造の粘性減衰エネ ルギー, $W_{h}^{b}$ は下部構造の粘性減衰エネルギー, $W_{p}$ は免震層の 累積塑性ひずみエネルギーを表す。また地震終了時の各エネル ギーと地震総入力エネルギー $W_{I}$ 及び最大変形（正負最大振幅の 平均值) $\bar{\delta}_{\text {max }}$ に対する累積塑性変形 $\bar{\eta}_{p}=W_{p} / \mu M g$ の比率を A ・ $\mathrm{B} \cdot \mathrm{C}$ 各モデルについて表 6 に示す。総入力エネルギーは下部構 造の剛性が低くなるほど（B，C，A の順に）増加している。地震 終了時の総入力エネルギーに占める各エネルギーの割合は, 免震

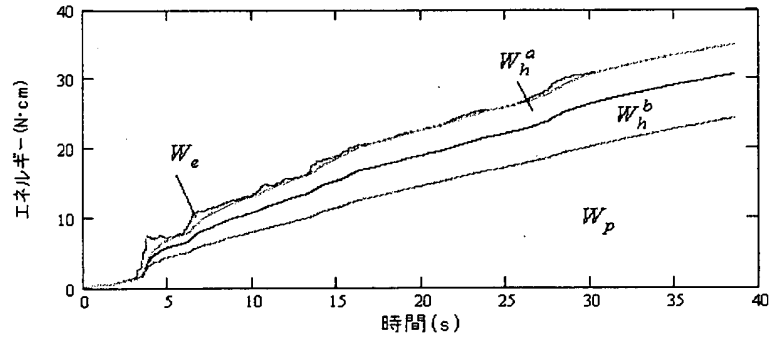

図 14 エネルギー応答の時刻歴 (C モデル・兔震時)
層の累積塑性ひずみエネルギーが最も大きく全体の50〜80\%を占 め, 以下，下部構造の粘性減衰エネルギー，上部構造の粘性減衰 エネルギーの順に小さくなっている。また下部構造の剛性が高く なるほど, 免震層の累積塑性ひずみエネルギ一の割合が増加し, 上部構造の粘性減衰エネルギーの割合が減少している。最大変形 に対する累積塑性変形の比率は下部構造の剛性が高くなるほど増 加し 10 を超えているが，この值を平均的に 8 とする秋山理論 ${ }^{15)}$ は本実験モデルに関しては安全側の評価を与えることになる。

総入力エネルギーの 50\%が免震層に入力されると仮定して，免 震層のエネルギーの釣合式 ${ }^{4)}$ よ, 免震層の最大応答変位及び最 大せん断力係数を，摩擦係数をパラメータとして予測した結果を 図 $15^{\circ}$ 及び図 16 に示す。ここで, 免震層に入力されるエネルギー が総入力エネルギーの 50\%と仮定したのは以下の理由による。表 6 に掠いて， $W_{p} / W_{I}$ は免震層に吸収される累積塑性ひずみエネ

表 6 各エネルギーと免震層の累積塑性変形

\begin{tabular}{|c|c|c|c|c|c|c|c|}
\hline モデル & $\begin{array}{c}W_{I} \\
(\mathrm{Ncm})\end{array}$ & $\begin{array}{c}W_{p} \\
(\mathrm{Ncm})\end{array}$ & $\begin{array}{c}W_{h}^{a} \\
(\mathrm{Ncm})\end{array}$ & $\begin{array}{c}W_{h}^{b} \\
(\mathrm{Ncm})\end{array}$ & $\frac{W_{p}}{W_{I}}$ & $\frac{\bar{\eta}_{p}}{\bar{\delta}_{\max }}$ & $\frac{8 \bar{\delta}_{\max }}{\bar{\eta}_{p}} \frac{W_{p}}{W_{I}}$ \\
\hline $\mathrm{A}$ & 24.7 & 12 & 4.8 & 7.9 & 0.49 & 10.8 & 0.36 \\
\hline $\mathrm{B}$ & 11.2 & 8.8 & 0.9 & 1.5 & 0.78 & 20.4 & 0.31 \\
\hline $\mathrm{C}$ & 17.7 & 11 & 1.8 & 4.9 & 0.61 & 14.1 & 0.35 \\
\hline
\end{tabular}




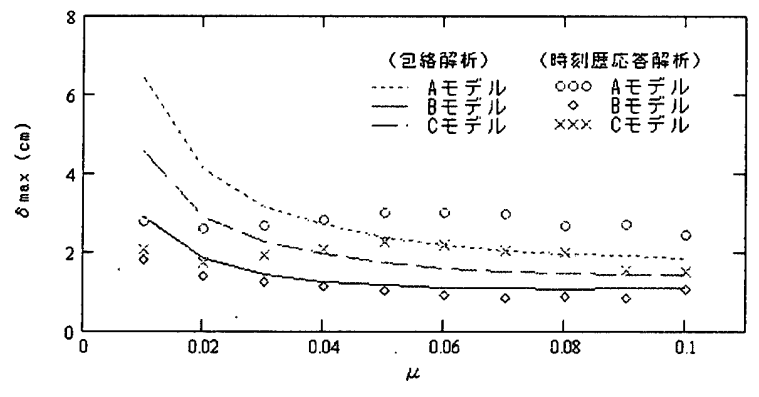

図 15 包絡解析法による免震層最大応答変位

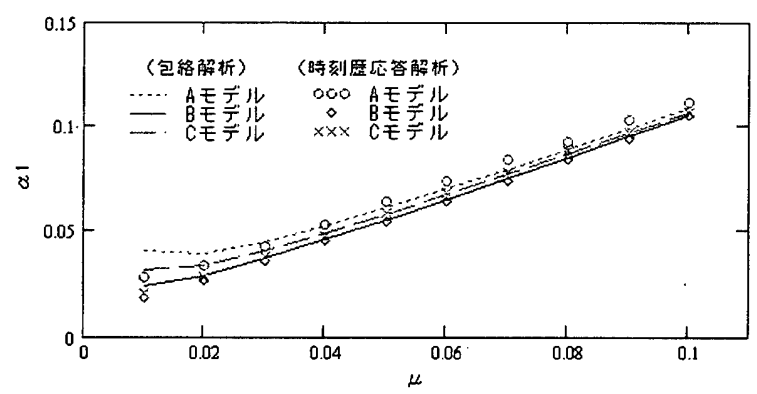

図 16 包絡解析法による免震層最大せん断力倸数

ルギーの総入力エネルギーに対する比率を， $\bar{\eta}_{p} / \bar{\delta}_{\max }$ は累積塑性 変形の最大変形に対する比率を示す。包絡解析法 ${ }^{4}$ で は $\bar{\eta}_{p} / \bar{\delta}_{\max }=8$; すなわち最大変形時の 2 サイクル分の累積塑性 ひずみエネルギーが免震層に吸収されると仮定している。そこで, $W_{p}$ のうち2 2 サイクル分が免震層に入力されるエネルギーである と考えると，その総入力ェネルギーに対する比率は $8 \bar{\delta}_{\max } / \bar{\eta}_{p} \cdot W_{p} / W_{l}$ となるが，この值はおおむね 0.4 以下の安定し た值となっており,ここでは安全側の評価として0.5を採用した。 ちなみに, 打越ら ${ }^{10}$ は免震ドームにおける同様の検討において 0.5 ０.7 を採用している。図 15 及び図 16 より，時刻歷応答解析の結 果と比較して, 概ね妥当な予測值が得られていると判断される。

\section{6. 結語}

本稿では，下部構造との間に転がり支承と積層ゴム支承の併用 による免震層の導入を想定した大スパンアーチ模型の振動台実験 を行い，免震化による応答低減効果や下部構造の剛性が全体系の 応答性状に及ぼす影響について検討した。さらに，実験のシミュ レーションを行い, シミュレーション手法 ${ }^{13)}$ の妥当性を検証する とともに, アーチ一免震層一下部構造連成系の振動性状とエネル ギー授受の関係について総括的考察を行った。

実験の結果，上部及び下部構造の応答は下部構造の剛性によっ て著しい影響を受けること，特に上部構造と下部構造の固有周期 が接近している場合や下部構造の剛性の不均一性が顕著な場合, 上部構造に過大な応答が生じることが示された。しかし，このよ うな場合でも, 下部構造との間に免震層を挿入することによって, 上部構造の応答が著しく低減され，本実験で想定した転がり支承 と積層ゴム支承の併用による免震デバイスが空間構造の免震化に 有効であることが検証された。また積層ゴム支承の併用が免震層 の残留変位の抑制に効果的であることが碓認された。ただし，免
震層を挿入することにより上下間の連成が弱まり，振動数によっ ては下部構造が主に振動するモードが励起されて, 下部構造の応 答が増大することもありうるので設計上注意が必要である。

\section{稄势立㣮}

1）日本建築学会：阪神・淡路大震災調查報告, 建築編-3, シェル·空間構 造, pp.219-346, 1997

2）石川浩一, 松本秀信, 小田憲史, 加藤史郎：剛性の異なる 2 本の柱で 支持された平行弦卜ラス梁の地震応答性状, 構造工学論文集, Vol.43B, pp.465-476, 1997.3

3）藤本益美, 小田雷史：支持フレームの影響を考慮した円筒 2 層立体卜 ラスの地震応答解析, 計算工学講演会論文集, pp.897-900, 1997.5

4）日本建築学会：免震構造設計指針（第2 次改訂），2001

5）加藤史郎, 中澤样二, 打越瑞昌, 大杉文哉, 向山洋一: 入力低減型支 持機構を有する大スパンドーム構造物の地震応答性状一免震層の降 伏せん断力倸数の影響について一, 日本建築学会構造系論文集, 第 518 号, pp.57-64, 1999.4

6）加藤史郎, 打越瑞昌, 大杉文哉, 中澤祥二, 向山洋一: 入力低減型支 持機構を有する大スパンドーム構造物の地震応答性状一下部構造の 剛性と重量の影響について一, 日本建築学会構造系論文集, 第 525 号, pp.71-78, 1999.11

7) 加藤史郎, 中澤祥二, 打越瑞昌, 向山洋一 : 入力低减型支持機構を有 する大スパンドーム構造物の地震応答性状一下部構造の不均一性が 応答に与える影響一, 日本建築学会構造系論女集, 第 532 号, pp.111-118, 2000.6

8) Kawaguchi, M., and Tatemichi, L: Seismic isolation systems and their application in space structures, Bridging Large Spans from Antiquity to the Present, IASS Symposium, Istanbul, Turkey, pp.217-228, 2000.5

9）日本建築学会 : シェル・空間構造の减衰と応答制御, 新シェル空間構 造セミナー, 2002.11

10）新宮清志, 福島欣哉 : 上下地震動を受けるシェル構造物の免震及び ファジイ制御, 日本機械学会論文集 (C編), 第60巻577号, pp.2999-3005, 1994.9

11) Matsui, T., Sugiyama, E., Qiao, F. and Hibino, T.: Toward the realization of seismically isolated large-span spatial structures: model test and simulation, Proc. of the International Conference on Advances and New Challenges in Earthquake Engineering Research, Hong Kong, pp.437-444, 2002.8

12）松井徹哉，喬鋒，森部康司，杉山映，江坂佳賢 : 風応答を考慮した大 スパンドームの免震化に関する検討, 第 11 回日本地震工学シンポジ ウム論文集, pp.1655-1660，2002.11

13）松井徹哉：サブストラクチャー法による下部構造との連成を考虑した 空間構造の地震応答解析, 日本建築学会東海支部研究報告, 第 41 号, pp.217-220, 2003.2

14) Vandier, J.K. et al: A mathematical basis for the random decrement vibration signature analysis technique, J. Mech. Design, Vol.104, pp.307-313, 1982

15）秋山宏：エネルギーの釣合に基づく建筑物の耐震設計，技報堂，1999

16）打越瑞昌, 加藤史郎, 中澤祥二, 向山洋一：入力低減型支持機構を有 する大スパンドーム構造物の地震応答性状一下部構造の塑性化の影 響とエネルギ一的考察一，日本建築学会構造系論文集，第 576 号， pp.95-102, 2004.2 